UDC 821.111-31.09 Austin J.

https://doi.org/10.18485/ms_zmskij.2020.68.1.8

Др Наташа В. Гојковић

\title{
ПРЕВОЪЕЊЕ АРХАИЗАМА И ИСТОРИЦИЗАМА С ЕНГЛЕСКОГ НА СРПСКИ ЈЕЗИК У РОМАНУ РАЗУМ И ОСЕЋАЈНОСТ ЏЕЈН ОСТИН: КРИТИЧКА АНАЛИЗА*
}

\begin{abstract}
Предмет проучавања у овом раду јесу преводи архаизама и историцизама у роману Разум и осећајности Џејн Остин на српски језик. Основно полазиште за анализу преводних решења у два постојећа превода поменутог романа (Милице Симеоновић из 1976. и Браниславе Маодуш из 2012) јесте универзално језичко обележје или tertium comparationis - трећи елемент, према којем се поређење врши. Анализирани су сви историцизми, док су архаизми који су уврштени у рад одабрани према два критеријума: 1. преводна решења се разликују у постојећим преводима и 2. ауторка нуди боље преводно решење. У уводном делу рада укратко се образлажу појмови архаизама и историцизама, наводе се речници који су коришћени при анализирању, објашњавају теоријска полазишта за истраживање и ближе се упознаје са задатком преводилаца у роману Разум и осећајности. Наредни део посвећен је детаљној анализи преводних решења архаизама и историцизама, у смислу упоређивања значења издвојених лексема са значењима постојећих преводних решења, те предлагања бољих у случајевима у којима је то потребно. Дефиниције значења лексема на енглеском језику преузете су искључиво из електронског издања речника Oxford English Dictionary, док су дефиниције значења српских лексема преузете из Речника срӣског̄a језика Матице српске и лексикона Синоними и сродне речи срйскохрвайског̄ језика. У трећем делу рада наводе се основни закључци анализе на нивоу језика Џејн Остин и на нивоу постојећих превода архаизама и историцизама, те се констатује да списатељичин језик није архаичан у толикој мери да буде неразумљив или теже разумљив данашњем читаоцу, а да од два постојећа
\end{abstract}

* Рад је изложен у виду саопштења на научном скупу Језици и кулйуре у времену и üростиору 3, Филозофског факултета у Новом Саду и представља део испитне обавезе у оквиру предмета Контрастивна лексикологија, под менторством проф. др Твртка Прћића. 
превода романа, према анализи превода архаизама и историцизама, бољим можемо назвати превод Милице Симеоновић.

Кључне речи: архаизми, историцизми, tertium comparationis, Разум и осећајности, превођење.

1. Увод. Предмет проучавања у овом раду јесу преводи архаизама и

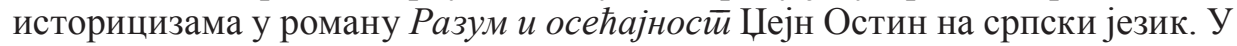
уводу укратко образлажемо појмове архаизама и историцизама, наводимо речнике који су коришћени при анализирању, објашњавамо теоријска полазишта за истраживање и ближе се упознајемо са задатком преводилаца у поменутом књижевном делу.

1.1. ДЕФИНИЦИЈА АРХАИЗАМА, ОБЕЛЕЖАВАњЕ И РЕЧНИЦИ. Oxford English Dictionary дефинише архаичне речи као оне које припадају неком ранијем времену, које нису више у општој употреби, а још их користе појединци, или су се задржале у специфичној употреби: поезија, литургија, итд. Имајући у виду ову дефиницију, из текста романа Разум и осећајност̄ (Sense and Sensibility) енглеске списатељице Џејн Остин издвојен је корпус од шездесет четири речи, за које се, према критеријумима који ће бити наведени касније, може рећи да припадају архаичном вокабулару. У овом раду обрађено је свих осам пронађених историцизама и двадесет архаизама према два критеријума: 1. преводна решења се разликују у постојећим преводима и 2. ауторка нуди боље преводно решење. Тиме је, уз констатовање разлика у асоцијативном обележавању речи у речницима који су коришћени, извршен први задатак ауторке овог рада. Други задатак подразумевао је проналажење преводних решења за издвојене речи у постојећим преводима на српски језик, и то: у преводу Милице Симеоновић из 1976. и Браниславе Маодуш из 2012. Трећи задатак и, могло би се рећи најважнији, свакако је анализа преводних решења и, у појединим случајевима, проналажење бољих.

Издвојени корпус формиран је на основу одредница асоцијативних обележја у издањима једнојезичних речника доступних на интернету (редослед по абецедном реду): 1. The American Heritage Dictionary of the English Language: www.ahdictionary.com, 2. The Chambers Dictionary: www.chambersharrap.co.uk, 3. Collins English Dictionary: www.collinsdictionary.com, 4. Merriam-Webster's Collegiate Dictionary: www.merriam-webster.com и 5. Oxford Dictionaries: British and World English: www.oxforddictionaries.com, затим у електронским издањима једнојезичних речника: Cambridge Advanced Learner's Dictionary, Second Edition (Cambridge University Press, 2005) и Oxford English Dictionary (Oxford University Press, 2009), те штампаном издању једнојезичног речника Collins COBUILD English Language Dictionary (Harper Collins Publishers, 1993). Осим помоћу наведеног, ауторка је према свом досадашњем познавању енглеског језика, субјективном селекцијом издвајала речи за које је сматрала да нису више у општој употреби. Овакав приступ делом је оправдан и самом суштином асоцијације као субјективне и факултативне компоненте значења. Дефиниције речи преузете су искључиво из 
електронског издања речника Oxford English Dictionary, док су дефиниције српских речи преузете из Речника срйског̄a језика Матице српске и лексикона Синоними и сродне речи срйскохрвайског̄ језика.

Најпре ће бити речи уопштено о архаизмима. Наиме, они настају из језичких разлога - стварањем савремених синонима. Можемо направити разлику између застареле и архаичне лексике, при чему се застарелом лексиком сматрају оне речи које више нису у употреби и замењене су другим лексемама, а архаичном лексиком сматрају се оне речи које имају стилску употребу (то смо видели и у оксфордској дефиницији архаизама, раније у тексту). У том смислу Џорџ Филип Крап (George Philip Krapp) упозорава да пука старост неке речи не значи нужно и њену архаичност. Наиме, он наводи да, на пример, речи he is постоје у енглеском језику у том истом визуелном облику још од времена краља Алфреда, те да се велики корпус енглеског језика састоји управо од речи које су далеко старије од оних које зовемо архаичнима. Дакле, „Оно што издваја један архаизам од осталих речи није то што је стар, него то што је након изласка из опште употребе преживео у извесним аспектима језика - дијалектском, поетском, литургијском, техничком“ (KRAPP 1927: 292).

Јасна Мелвингер (1984) наводи да можемо разликовати неколико врста архаизама: лексичке, садржајне (семантичке), лексичко-творбене и лексичко-фонетске архаизме. Да бисмо илустровали ове појаве, послужићемо се примерима из романа Разум и осећајносй. Лексички архаизми подразумевају ситуацију када је једна лексема замењена другом: never уместо nay. Садржајни архаизми су лексеме код којих је једно од значења застарело, нпр. address, чије се некадашње значење „начина опхођења према саговорницима“ сматра архаичним, а задржало је значења „место становања, улица и број“, „званично обраћање, говор присутном аудиторијуму“ итд. Лексичко-творбени архаизми представљају лексеме којима је неки од творбених елемената застарео, нпр. у облику за треће лице једнине у презенту глагола have - hath. Лексичко-фонетски архаизми су лексеме код којих постоји застарелост на гласовном плану, нпр. афектирани облик придева old - olde.

Историцизми су лексеме које нису у употреби зато што реалије које су њима обележене више не постоје, истиче Јасна Мелвингер (1984). На њихов настанак утичу нејезички разлози, за разлику од архаизама, чији настанак узрокују језички. Историцизми постају активни у одређеним ситуацијама, али не и у свакодневном комуницирању. С обзиром на то да су ове лексеме, ишчезавањем предмета и појава које именују, у директној вези са духом времена који су преводитељке морале да пренесу савременом читаоцу, ауторка овог рада одлучила је да их уврсти у свој корпус и анализу.

У речницима срећемо различита обележја за лексеме које нису више у употреби, или им се променило значење, или се употребљавају у врло суженом контексту. Tо cy: arch, old-fash, old use, obs, lit, poet, dated, rare. ${ }^{1}$ Пре

1 Занимљиво је и очекивано да се најмање лексема обележених ca $\operatorname{arch}$. нашло у речнику из 1993. (Collins COBUILD English Language Dictionary), готово ниједна. Међутим, овај 
него што приступимо анализи поменутог корпуса, морамо се осврнути на

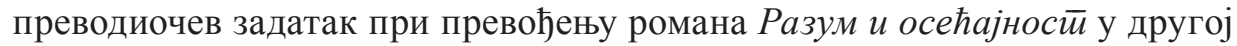
половини XX века, романа написаног крајем XVIII века и објављеног 1811. У наредном потпоглављу навешћемо питања у вези са темом овог рада, а која су две преводитељке морале имати у виду, без велике намере да се са становишта „свезнајућег аутора“ критикује нимало лак преводилачки посао.

1.2. TERTIUM COMPARATIONIS: JЕЗИК ЏЕЈН ОСТИН И ЗАДАТАК ПРЕВОДИЛАЦА. ПрвО питање је свакако питање социоисторијског тренутка у којем се одвија радња романа, са свим специфичностима које се у великој мери одражавају на језик којим говоре ликови у роману. Преводилац мора све време да буде свестан удаљености тренутка у ком преводи од онога у којем се дешава радња романа и потребе да језик извора у преводу не изгуби своју специфичну патину, али ни разумљивост модерном читаоцу. Ова проблематика у вези је са хронолекатским обележјима лексеме (в. Прћић 2008). Даље, преводилац оваквог романа (у крајњој линији и било којег другог) размишљајући о социоисторијском тренутку мора да познаје свет ликова у роману - манире, навике, правила понашања и хијерархијска обележја, да би исправно пренео у систем језика превода сложену матрицу дијалога између различитих друштвених група: мушко - женско, припадници вишег друштвеног слоја наспрам припадника нижег, старији - млађи итд. Овде се ради о познавању социолекатских обележја лексема, као и интерперсоналног регистра (Прћић 2008). Већ сада видимо да је посао преводилаца веома захтеван, а навели смо заправо само једно питање којем се морају посветити. Уопштено говорећи, преводилац мора да поседује комуникайивну компетенцију (Прћић 2008: 40), која у домену стилистике, у конкретном случају обухвата способност адекватног одабирања лексичких јединица и способност адекватног прилагођавања различитим комуникационим ситуацијама, што претпоставља познавање асоцијативног значења. Не говоримо овде о кодној компетенцији (Прћић 2008: 39), јер је она неизоставни предуслов комуникације. Напослетку, неопходно је и поседовање знања о свету и примена тог знања да би се успешно остварило преношење поруке из језика извора у језик превода.

Све што је претходно наведено, иако смо имали у виду роман Разум $u$ oceћajности, могло би (и морало би) да се примени на поступак превођења било којег текста. За ову тврдњу налазимо потврду код Најде, који је увео појам динамичке еквиваленције:

\footnotetext{
речник бележи највише old-fash. одредница - двадесет две. Највише архаичних лексема, те тако и обележених, нађено је у он-лајн издању Oxford Dictionaries: British and World English који такође бележи и обележје dated у шест случајева. То обележје се појављује још само у издању речника The Chambers Dictionary, које је доступно на интернету. У овом другом налазимо и обележје poetic, које је нађено још само у речнику Collins English Dictionary, где смо пронашли и обележје rare, које нема у другим речницима. Још једна занимљивост уочена је у речнику Merriam-Webster Online: Dictionary and Thesaurus, а тиче се обележја old-fash. и lit, која се појављују заједно, као алтернатива old-fash. or lit. код већине испитиваних лексема.
} 
„Динамичка еквиваленција (...) требало би да буде дефинисана у смислу степена истоветности реакције прималаца поруке на језику превода и прималаца поруке на језику извора. Ова реакција никада не може бити идентична, јер постоји велика разлика у културолошком и историјском окружењу, али би требало да постоји висок степен еквиваленције у реакцији, у противном, превод неће испунити своју сврху““ (NIDA - TABER 1969: 24). ${ }^{2}$

Али какву још грађу преводилац мора да познаје под условом да влада поменутим језичким вештинама? Пре свега, мора да поседује макар минимално знање о епохи у којој је живела и писала Џејн Остин, дакле, о Британији с краја осамнаестог века и почетка деветнаестог. У историји књижевности и историји уопште, овај период дели се на два значајна периода: Џориијанско доба ${ }^{3}$ и Доба регеенйстив $a^{4}$. Преводилац би, зарад што вернијег преношења теме и тона романа, морао да познаје основне карактеристике ових периода. Ту спада, пре свега, значај друштвених правила која ће свој пуни рестриктивни облик добити за време владавине краљице Викторије: суздржаност у говору и понашању, немогућност девојака да било куда иду без пратње, одсуство обимније комуникације писмима између девојке и младића, балови као места за упознавање будућих супружника, правно непостојање жене уколико није удата и, следствено томе, важност удаје и остварење улоге мајке. Друга важна карактеристика је снажан узлет више средње класе и аристократије, те стварање све већег јаза између нижих и виших слојева друштва. У том смислу, чињеница важна преводиоцу свакако је и готово потпуно одсуство ликова из нижих друштвених слојева, самим тим и социолекта карактеристичног за њих. Ово је, заправо, потпуно у складу са двоструком сликом коју је Доба регентства о себи изнедрило јер, како Кероли Ериксон запажа, „испод површинског сјаја живота у Доба регентства - луксузни ентеријери, елегантна одећа, велелепна, питорескна архитектура - крила се опака слабост, прожимајућа празнина и осећај губитка, који су погађали широки спектар друштва““ (ERICKSON 1986: 8).

2 ,Dynamic equivalence (...) is to be defined in terms of the degree to which the receptors of the message in the receptor language respond to it in substantially the same manner as the receptors in the source language. This response can never be identical, for the cultural and historical settings are too different, but there should be a high degree of equivalence of response, or translation will have failed to accomplish its purpose“" [Превела: Н. Г.].

${ }^{3}$ Џорџијанско доба - Georgian Era (енгл.), период између 1760. и 1811, када је Великом Британијом владао Џорџ III, први краљ из породице Хановер који је рођен на енглеском тлу.

${ }^{4}$ Доба регентства - Regency Period (енгл.), период између 1811. и 1820, када је Великом Британијом владао Принц регент (касније Џорџ IV), син Џорџа III, тада тешко болесног и проглашеног неподобним за управљање земљом.

5 ,For beneath the surface glitter of Regency life - the opulent interiors, the elegant dress, the grand, scenic architecture - was an underlying malaise, a pervasive emptiness and sense of loss that afflicted a wide spectrum of the populace" [Превела: Н. Г.]. 
Иако је и у књижевности и на филму ово доба представљено махом тим „површинским сјајем”, морамо имати на уму да је период између 1760. и 1820. био период који је забележио рат за америчку независност, наполеонске ратове, уставна превирања, нагли пораст броја становника у градовима, што је резултирало бујањем сиротињских четврти, а тиме и насиља, проституције и лоповлука.

Једно интересантно истраживање на тему карактеризације ликова у роману путем веће или мање употребе речи латинског порекла (DEFOREST MARGOLIES - JOHNSON 2000) показало је да су они ликови који користе већи проценат енглеских речи латинског порекла образованији и вишег друштвеног статуса, док они ликови који користе већи проценат речи германског порекла, у свету Џејн Остин, углавном су људи нижег сталежа или слабијег образовања. Такође, установљено је да је списатељица лицемерје и помпезност, осим традиционалним начинима, ликовима у својим романима приписивала и управо чешћом употребом речи латинског порекла. Језик самог наратора у њеним романима заправо је језик хероина романа. Уско у вези са епохом је и критички и сатирични став Остинове према њој, те у том смислу преводилац има задатак да пренесе језичке финесе и да одабиром лексема очува списатељичину намеру.

Видимо да је Џејн Остин у великој мери користила језик као оруђе за испуњавање различитих задатака једног романописца, а наш задатак у овом раду је да утврдимо како су архаизми и историцизми у роману Разум и осе$\hbar a j н о c \bar{u}$ преведени на српски језик, постоји ли разлика у њиховом превођењу у постојећим преводима, између којих је временска дистанца од готово четири деценије, као и покушај да се у неким случајевима понуде боља преводна решења.

Размишљајући о наведеним задацима који стоје пред преводиоцем, видимо да су они део контрастивне анализе која се служи превођењем и служи превођењу (Ивир 1985: 84). У преводу се, наиме, „откривају тзв. преводни еквиваленти, односно, категорија/категорије језика Б којима се може превести једна категорија језика A“ (ЂорЂевић 2000: 3). На овај начин откривају се сличности и разлике међу језицима. Преводилац, дакле, у својој пракси за циљ има да пронађе преводни еквивалент, који је, опет, у контрастивној анализи средство рада. Видимо да су теорија превођења и контрастивна анализа неодвојиве.

Оно што представља радну основу контрастивне анализе свакако је универзално језичко обележје или tertium comparationis - трећи елемент према којем се поређење врши (ЂоръЕвић 2000: 54). Поједностављено речено, поређење, тачније упоредивост категорија у два језика, може се установити на основу дефиниције значења ових категорија. Стога, када говоримо о еквиваленцији, говоримо о приближној значењској једнакости. Упоредивост можемо утврдити и тражећи одговор на питање који елементи у систему језика А одговарају елементима у језику Б. Када се та веза успостави, успостављена је кореспонденција, што значи да су нађени и формално и значењски 
подударни елементи два језика, односно, кореспонденти два језика. Како Радмила Ђорђевић (2000: 62) истиче, с обзиром на то да се кореспонденција схватала искључиво формално, називана је формалном кореспонденцијом.

Резултати овог рада у највећој могућој мери добијени су исцрпном анализом значења издвојених лексема. Било је потребно користити релевантне изворе значења, упоредити сама значења и утврдити у којој мери се она поклапају. Иако је нађен велики број формалних кореспондената, акценат је при анализирању био на преводној еквиваленцији због природе примарне литературе - романа који представља комедију нарави - и њене често веома суптилне ироничне ноте, коју непажљиво превођење може у потпуности избрисати. Такође, преношење духа епохе је у уској вези са одабиром преводних решења, те она нису задовољила формални ниво сличности у случајевима у којима на српском језику преводни еквивалент тачније преноси поруку. С обзиром на специфичност лексема којима се рад бави - архаизама, а нарочито историцизама, важан део анализе представљало је и коришћење визуелних извора (слике са интернета, фотографије), музејских извора (артефакти) и секундарне литературе о некадашњем начину живота (нпр. о друштвеним правилима, запрежним возилима, архитектури, исхрани, итд.).

2. АНАЛИЗА ПРЕВОДА АРХАИЗАМА И ИСТОРИЦИЗАМА НА СРПСКИ ЈЕЗИК. ЗаПОчећемо анализу превода архаизама и историцизама у роману Разум и осећај-

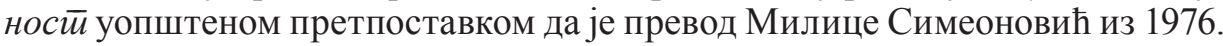
приближнији енглеском извору, него превод Браниславе Маодуш из 2012, што ћемо настојати и да аргументујемо даље у раду. Наравно, морамо имати на уму да се оваква претпоставка заснива искључиво на реченицама у којима су пронађени архаизми. На самом почетку анализе навешћемо два кључна аргумента за поменути закључак: први се односи на чињеницу да се у неколико наврата превод Браниславе Маодуш удаљава од оригинала у толикој мери да промени смисао поруке. На пример, у оригиналу реченица гласи: „... she did not, at thirteen, bid fair to equal her sisters at a more advanced period of life.“ У преводу гласи овако: „,... у својој тринаестој години није мог̈ла да се мери са много зрелијим сестрама." С обзиром на то да to bid fair, према дефиницији у речнику Oxford English Dictionary, говори о могућности, вероватноћи, оправданим изгледима за дешавање нечега ${ }^{6}$, јасно је да је смисао поруке потпуно измењен. Преводитељка констатује садашње стање, уместо да пренесе списатељичину поруку о томе да се сада већ види да најмлађа сестра неће моћи да се мери са своје две старије сестре када дође у зрелије доба. Слични примери биће наведени касније. Други аргумент односи се на изостављање појединих речи у преводу, на пример: „Управо овој кући почела је почетком јануара да управља своје мисли, и изненада, сасвим неочекивано, позвала је и две старије госпођице Дешвуд да јој праве

${ }^{6}$ To bid fair $=$ to offer with reasonable probability, to present a fair prospect, seem likely. Orig. with for and object; now also with inf. 
друштво.“ Имајући у виду извор, у којем се каже: „Towards this home, she began on the approach of January to turn her thoughts, and thither she one day abruptly, and very unexpectedly by them, asked the elder Misses Dashwood to accompany her.", видимо да је изостављен превод прилога thither. Можда се на први поглед не чини да изостављање нарушава преношење поруке. Међутим, у ширем контексту, када знамо да се ради о томе да је госпођа Џенингс имала обичај да проводи дуже време код својих ћерки, а сада има намеру да проведе неко време у својој кући и да од свих својих потенцијалних резиденција старије госпођице Дешвуд позива баш у сопствену, чини се да је изостављање прилога неоправдано. Морамо додати још једну примедбу на анализирану реченицу, иако није у питању архаизам: израз to accompany her морамо тумачити у светлу некадашњег обичаја да младе девојке, у годинама за удају, бивају позиване код рођака или пријатеља у Лондон у току сезоне балова, са циљем да упознају потенцијалне младожење. Превод Браниславе Маодуш, ,да јој ираве друщииво”, асоцира одмах на улогу дружбенице, прекраћивање времена, разоноду у часовима доколице. Она која позива неудате младе даме у своју кућу на дужи боравак има обавезу пратиље, проводаџике, моралне саветнице, те иако јој те младе даме заиста и прекраћују време, то је тек пратећа пријатност главним обавезама. Дакле, иако енглески извор говори само о пратњи, ми морамо узети у обзир све наведено, те тако решење „да јој ирраве друщитво” делује површно. Предложили бисмо „да јој се иридруже и иоссиинуюене шимићенище”.

2.1. АНАЛИЗА ПРЕВоДА ИСТОРИЦИЗАМА. Следећи задатак је да анализирамо неколико историцизама који се појављују у роману. Лексеме које припадају овој врсти су следеће: barouche, demesne, gig, stage, post, enfranchisement, chaise и glebe.

Лексему barouche, Oxford English Dictionary дефинише као кочију на четири точка, са покретним полукровом и наспрамним седиштима за два пара и једним седиштем напред, за кочијаша. У издању Wordsworth Classics, у напоменама на крају романа, наведена је такође дефиниција ове лексеме, према којој се ради о кочији на четири точка која може удобно да прими четири особе, са додатна два места на задњем делу. Милица Симеоновић определила се за превод лексемом кочија, док се Бранислава Маодуш одлучила за лексему фијакер. Речник срйског̄а језика Матице Српске дефинише лексему кочија као „нарочийа зайрежна (коњска) кола за йревоз ииуйника, обично са йокрешиним кровом или зайворена”, уз примедбу „мађ”. Лексема фијакер дефинисана је као „лакщи йуйничка зайрежна кочија са йокрейним кровом”, уз примедбу „франц”. Пажљивим анализирањем старих фотографија у књигама и слика на интернету ауторка је дошла до закључка да је бољи превод кочија, јер фијакер најчешће може да прими два путника, пошто су седишта за друге две особе практично помоћна, што не задовољава услов удобно, наведен у дефиницији из напомена романа.

Задржаћемо се још код запрежних превозних средстава да одмах објаснимо лексеме gig и chaise. Лексему gig Oxford English Dictionary дефинише 
као лаки једнопрег на два точка. У преводу из 1976. употребљена је лексема двоколице, а у преводу из 2012. лексема кочије. Морамо да констатујемо да је лексема кочије неприхватљива, јер подразумева четири точка, што значи да се лексема gig и преводно решење кочије не поклапају према једном од основних дијагностичких обележја - броју точкова. Лексема двоколице је боље решење, што се види и у дефиницији коју за ову лексему даје Речник срйског̄a језика Матице српске: „запрежна кола, кочија на два точка”. Могуће решење би била још и лексема чезе, с обзиром на то да се ради такође о запрежним колима на два точка, али пошто се даље у роману појављује лексема chaise, и у оба превода се за њу нуди решење чезе, остаћемо при лексеми двоколище. Што се лексеме чезе тиче, морамо бити веома опрезни. Наиме, Oxford English Dictionary напомиње да chaise подразумева лако запрежно возило на два или четири точка, у зависности од случаја. Штавише, наводи да се шире схваћена, ова лексема може користити при именовању било којих лаких кочија и колица. Речник срииског̄ језика чезе дефинише као реч мађарског порекла која представља лака путничка запрежна кола на два точка, лаки фијакер. Ова дефиниција би могла да се поклапа са оксфордском према дијагностичком обележју броја точкова, тачније, ширем дијапазону могућности него што је то случај код двоколица. Такође, морамо имати у виду и број упрегнутих коња, јер Oxford English Dictionary наводи да се лексема chaise користила за једнопрег пре употребе поштанских кочија, те је дефинише као chaise and pair - кочије на четири точка, са два коња и chaise and four - кочије на четири точка, са четири коња.

Разматрајући претходно наведене лексеме и реалије које оне обележавају, можемо се запитати колико су различита преводна решења данашњем читаоцу заиста важна. Сматрамо да је проналажење што приближнијег преводног решења за овакве лексеме један од начина да се читаоци подстакну да и ван романа потраже податке о изгледу и употреби некадашњих превозних средстава, што може само обогатити њихова сазнања, како о историји тако и о језику.

Дефиниција лексеме demesne говори о простору директно спојеним са властелинском кућом, дакле, делом имања који није издат у најам. У конкретном случају, простор је мало зелено двориште које се види са предње стране Бартонског летњиковца. Милица Симеоновић превела је лексему demesne као имање, што представља појам шири од онога како енглески извор дефинише Oxford English Dictionary, али је свакако бољи од решења вр $\bar{u}$, који је понудила Бранислава Маодуш и који, осим што представља само један од начина на који се део имања који није издат у најам може искористити, такође и мења смисао: двориште пуно зеленила представља једини део имања који није под закупом, а налази се с предње стране куће и није то двориште део врта, како закључујемо из поменутог превода. С обзиром на то да се део поседа који није под закупом, него је у директном власништву поседника имања, може искористити како за разоноду (парк, коњске трке с препонама, итд.), тако и за потребе домаћинства (узгој поврћа, 
воћа, стоке), врй би представљао само недијагностичко обележје лексеме uмaнe.

Још једна лексема која се тиче поседа је и лексема glebe. Oxford English Dictionary дефинише ову лексему као земљу додељену свештенику на име његових, некада феудалних, права. Наиме, све до 1978. та земља и приход од ње припадали су свештенику за његовог живота. Црквено имање и йарохијско имање су понуђени преводи и ауторка сматра да су прихватљиви, јер имање о којем је реч суштински припада цркви, с обзиром на то да наследници свештеника који је тренутни уживалац прихода, немају права на њега.

Наредни историцизам је лексема enfranchisement. Oxford English Dictionary наводи да се ова лексема и фигуративно користи, а дефинише је као ослобођење из заточеништва, заробљеништва, ропског положаја или политичке подређености. Део реченице у којој је ова лексема употребљена гласи: ,$\ldots$ and it was altogether an attention which the delicacy of his conscience pointed out to be requisite to its complete enfranchisement from his promise to his father." И поново је превод Милице Симеоновић коректнији од превода Браниславе Маодуш. Наиме, у првом случају, преводитељка нуди као решење лексему разрешити (,,а то би, у сваком случају, била пажња која би, према наговештајима његове осетљиве савести, била потребна да се она потпуно разрещи обећања датог оцу.”), док се у другом нуди лексема задовољитии (,а управо је то била она врста пажње коју је истанчаност његове савести захтевала да би могао да сматра да потпуно задовољава обећање које је дао оцу.”). С обзиром на то да лексема enfranchisement имплицира акт ослобађања, лексему задовољииии не можемо сматрати добрим преводом, јер се тиме губи управо најважније дијагностичко обележје изворне лексеме. Оно је уједно овде и фигуративно употребљено, што носи посебан ефекат, јер је контекст такав да дато обећање за Џона Дешвуда представља истински терет којег се на сваки начин настојао решити. То што је добио идеју како да уз најмањи могући напор и супротстављање супрузи то обећање испуни, за њега је представљало истинско скидање окова. Зато ауторка овог рада предлаже као решења још и одрешииии (које има помало религијски призвук), ослободийи (према ДгО, најближе извору) и растиерешиийи (према ДгО најдаље, али према лексеми савес $\bar{w}$, на коју се односи, најближе као колокација). Такође, ауторка сматра да није било неопходно мењати врсту речи, те да је преводно решење могло да остане у облику именице, како је у оригиналу.

Заокружићемо овај део рада о историцизмима са две лексеме које означавају поново запрежна превозна средства: stage и post. Овде ћемо најпре покушати да разјаснимо које реалије означавају ове лексеме, с обзиром на то да су и једна и друга скраћени изрази за превозна средства која именују. Наиме, према дефиницијама из оксфордског речника и фотографијама нађеним на интернету, можемо да претпоставимо да лексема stage представља скраћену верзију лексеме stage-coach. Преводи ове лексеме били би йомйанска кочија или дилижсанса, с тим да друга лексема има и обележје „франц.” Дефиниција каже да је у питању кочија која сваког дана или одређеним 
данима у недељи превози путнике, пакете и сл. од места до места. Са лексемом post било је мало теже пронаћи право значење. Наиме, први импулс при превођењу свакако је тај да и ово превозно средство има везе са поштом. Међутим, пажљивијим истраживањем у речнику видимо да постоји лексема post-chaise, која је дефинисана као путничка кочија која се унајмљује од станице до станице, или се за њу унајмљују коњи у ту сврху, те да се то post односи на управо на станице. Занимљиво је да је једно од ДгО за ову лексему специфично место кочијаша: на коњу. Нема помена о преносу поштанских пакета, што чини битну разлику у ДгО у односу на поштанску кочију. Такође, оно што ову врсту кочије разликује од поштанске, постојање је предњег прозора, и то управо захваљујући чињеници да је кочијаш (постиљон) на коњу (најчешће левом), а уколико је потребан, додатни седи на седишту издигнутом изнад ковчега за пртљаг. Даље, када узмемо у обзир контекст у којем се ове две лексеме појављују, уочавамо да се о поштанској кочији говори са презиром, а да се о post-chaise говори као о нечему престижном. $\mathrm{У}$ једном од примера за post-chaise у оксфордском речнику видимо да је она резервисана за богате: At the commencement of the present century...communication between the smaller towns was by post-chaise... for the wealthy. Пошто је госпођици Стил, која говори о путовању овим превозним средствима, изузетно важно да је сматрају отменом и пријатељицом утицајног света (што може да закључи и мање брижљив читалац), сматрамо да је оправдан закључак да је списатељица употребивши лексему post, мислила на post-chaise. У том смислу, преводна решења за лексему stage, дилижанса и обична йоuйанска кочија можемо сматрати коректним. Решења за post, међутим, не можемо прихватити: Милица Симеоновић нуди лексему йощйанска кола, док Бранислава Маодуш нуди лексему дилижанса. Дилижсансу, Речник срйског̄ језика дефинише као велика затворена кола са коњском запрегом, која су служила за превоз путника, робе и поште. С обзиром на то да смо установили да post-chaise нема међу својим ДгО пренос поште, ова решења не можемо прихватити. У недостатку посебне лексеме за врсту кочије која има предњи прозор, ауторка предлаже лексему кочија („нарочита запрежна (коњска) кола за превоз људи, обично с покретним кровом или затворена“), која није довољно прецизна, али управо због дефиниције у којој се не помиње превоз робе и поште, најприближније одговара извору. Прецизније одређење постигли бисмо додавањем придева раскощна и йуйничка, те тако засигурно елиминисали могућност превоза поште и робе.

2.2. АНАЛИЗА ПРЕводА АРХАИЗАМА. У овом делу рада бавићемо се анализом оних архаизама из романа за које ауторка нуди боље преводно решење, као и оних чија се решења разликују у два постојећа превода. Први од таквих архаизама је лексема address. Oxford English Dictionary дефинише ову лексему као начин на који се разговара са другом особом, понашање при разговору (Manner of speaking to another, bearing in conversation; accost.). Превод из 1976. нуди начин ойхођењ $а$, док у преводу из 2012. налазимо лексему 
уг̄лађености. Сматрамо да је први превод боље решење, јер покрива ДгО

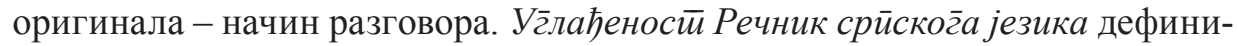
ше као поседовање лепих навика, понашања, али не говори се конкретно о

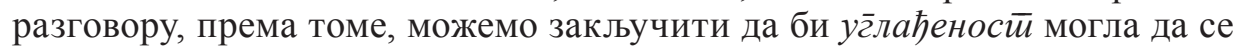
испољи при разговору, али исто тако и у другим друштвеним ситуацијама. Сходно томе, начин ойхођењ $а$ ближе одређује лексему address. Наравно, не смемо занемарити ни социоисторијски контекст: манири су у време Џејн Остин били изузетно важан део друштвеног пејзажа, а кршење устаљених правила говора и понашања озбиљан преступ. Зато је начин опхођења нешто што особу оног времена препоручи отменом друштву или га за исти дисквалификује.

Следећи архаизам је лексема nay (,Nay, the longer they were together the more doubtful seemed the nature of his regard; ...”), која има двојако значење:

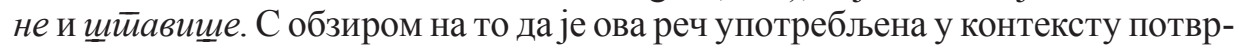
ђивања неверице и додатног образлагања разлога за то ${ }^{7}$, ауторка сматра да је бољи превод лексемом uㅡавище , коју је употребила Милица Симеоновић (,Шійавище, уколико га је чешће виђала, све је више сумњала у природу његове наклоности;...“). Други превод гласи овако: „Не. Што су више времена проводили заједно, то јој се природа његове привржености чинила неизвеснијом, ...“.

Hence је лексема коју Oxford English Dictionary дефинише као прилог који говори о удаљености од места на којем је говорник (At a distance from here; away.). Милица Симеоновић је реченицу „So far from hence!” превела као “Тако далеко одавде!”, док се Бранислава Маодуш одлучила за „Тако далеко!”. Поново морамо да се сагласимо са првим преводом, јер се лексема одавде поклапа управо са дефиницијом лексеме hence. У другом преводу се само имплицира удаљеност од места са којег се води разговор и нема лексичког нити контекстуалног оправдања за непревођење лексеме hence. Не бисмо смели превидети ни атмосферу у којој се дијалог одвија, то јест Едвардово непријатно изненађење због сазнања да Дешвудови одлазе далеко од Норланда ${ }^{8}$, тако да превођење лексеме hence доприноси и тону дијалога.

Архаизам vexed подразумева стање узрујаности, изнервираности, изиритираности. Извор гласи овако: „Не really felt conscientiously vexed on the occasion.“ Преводно решење Милице Симеоновић гласи: „Тада га је стварно пекла савест.“" Превод Браниславе Маодуш, „он се искрено узрујао због оваквог

7 ,She was far from depending on that result of his preference of her, which her mother and sister still considered as certain. Nay, the longer they were together, the more doubtful seemed the nature of his regard; and sometimes, for a few painful minutes, she believed it to be no more than friendship" (Austen 2000: 14).

8 „Edward turned hastily towards her on hearing this, and in a voice of surprise and concern, which required no explanation to her, repeated, 'Devonshire! Are you indeed going there? So far from hence! And to what part of it?' She explained the situation. It was within four miles nortward from Exeter" (AUSTEN 2000: 16). 
развоја догађаја“, приближнији је извору не само због тога што је правилно преведена сама лексема него и због контекста романа. Наиме, лик из романа који се узрујао је Џон Дешвуд, полубрат госпођица Дешвуд, исти онај чија савест има потребу да буде разрешена обавезе дате заједничком родитељу. Оно мало помоћи полусестрама, коју је он замислио као испуњење обећања оцу, њиховим пресељењем у Девоншир постало је неизводљиво. Далеко од тога да га је пекла савест, штавише, он је забринут што ће можда морати на други начин да им буде од помоћи, конкретно, финансијски, што би му било нарочито неугодно.

Наредни архаизам је заменица уе, некада употребљавана у другом лицу као множина од thou у номинативу и вокативу. Такође, употребљавала се и у једнини као израз нарочитог поштовања (што би био еквивалент српском ви). Милица Симеоновић превела је ову лексему као $\bar{u} u$ (,А ти, $\bar{u} u$ добро познато дрвеће!“), док ју је Бранислава Маодуш превела са ви („А ви, ви добро знана стабла!“"), што сматрамо бољим и тачнијим преводом. Лексема уе у роману је употребљена у обраћању стаблима у парку (у вокативу и у множини), које породица Дешвуд оставља за собом одлазећи у Девоншир.

Лексема offices у време Џејн Остин означавала је различите просторије у којима су се одвијали сви послови од којих је зависило једно домаћинство (прање веша, посуђа, кување) и у којима су се складиштиле намирнице попут хлеба, маслаца, вина, а неке од таквих просторија служиле су за држање постељине, столњака, сребрног посуђа итд. У преводу Милице Симеоновић стоји сйоредна одељењ $а$, а у преводу Браниславе Маодуш кухиња, вещерница. Нигде у роману не стоји прецизно за шта су служиле ове просторије у Бартонском летњиковцу, тако да се морамо ослонити на уопштени опис који даје Oxford English Dictionary. У том смислу, превод сйоредна одељењ $а$ управо својом уопштеношћу даје могућност да се у новом дому Дешвудових или налазе све наведене просторије или само неке од њих. Предлажемо још и иомоћне иростиорије.

Mirth, ведрина духа, која се манифестује смехом и шалом, своје преводе има у лексемама веселос $\bar{u}$ и срдачнос $\bar{w}$, при чему веселос $\bar{u}$ (особина или стање онога који је весео, добро расположење, радост, ведрина) боље покрива дефиницију коју даје Oxford English Dictionary - веселост духа која се испољава шалом и смехом - док бисмо за лексему срдачносй (особина онога који је срдачан - љубазност, предусретљивост) могли тек у недијагностичким обележјима наћи веселост и добро расположење.

Лексема сањарење се нашла у оба превода романа за лексему reverie. С обзиром на то да је реч о одсутном размишљању, медитирању, сањарење може да буде прихваћено, али ауторка овог рада нуди лексему снайрење, као поетичнију, имајући у виду емотивно стање Меријен Дешвуд, за коју се ова лексема у неколико наврата употребљава.

Партиципни придев dashing описује особу која се облачи и понаша упадљиво и по последњој моди. То је уједно у роману и идеал изгледа и понашања који би мајка и сестра Едварда Ферарса радо да му наметну. Милица 
Симеоновић преводи ову лексему као разметиљьв, а Бранислава Маодуш као г̄издав. Речник срииског̄а језика објашњава реч г̄uздав као а) богато украшен, накићен, раскошан (за одело) и б) који пада у очи својом лепотом и лепим оделом, диван, отмен (за момка или девојку). Дакле, дефиниције се делимично поклапају. Размейльи има негативну конотацију и није нужно у вези са одевањем, него се најчешће тако описује нечије понашање - који се размеће, хвалише, хвалисав. Јасно је да г̌издав приближније описује неког ко је dashing, тако да бисмо овај превод оценили као бољи.

Придев genteel је архаизам код којег у преводима нема нарочитог разилажења, али су српски кореспонденти интересантни за разматрање, па ћемо се овде позабавити њима. Наиме, у преводу из 1976. стоји уг̈лађени, а у преводу из 2012. стоји оймени. Речник срйског̄a језика каже да је онај ко је углађен стекао лепе навике и понашање, а да је оно што је углађено отмено и љубазно. Лексему оймен дефинише као фин, углађен, префињен, господствен укус, одело итд. За особу која је отмена каже да се одликује углађеним, господственим држањем, понашањем, манирима. Дакле, готово да се једна лексема дефинише другом. Разлика је, можда, једино у томе што се стиче утисак да се уг̈лађеним постаје, дакле у питању је процес, јер морамо имати у виду и израз ,уг̈ладио се“, тј. стекао лепе навике и понашање, као и дотерао се, улепшао се.

За брата Едварда Ферарса, Роберта, Луси Стил каже да је сохсотb. У преводу из 1976. он је замлат̄а, а у преводу из 2012. он је кицощи. Oxford English Dictionary дефинише ову лексему као будаласту и уображену особу, ташту на своја достигнућа и свој изглед. Речник др Семјуела Џонсона каже да је coxcomb неко површан, ко се претвара да има знање и постигнућа. Замлайа је, према Речнику срйског̄а језика, онај који се млати, замлаћује, блескаст, неотесан човек. Кищо је, пак, онај који воли да се кицоши, кити, облачи по моди, фићфирић, или неко ко је пробирач. С обзиром на то да је карактеризација Роберта Ферарса веома успешно урађена, читалац схвата да је он и будаласт и уображен, и да је површан и да воли да се облачи по моди. Лексема замлайа има и другу конотацију, заправо, у основи израза је млатарање рукама и ногама, тј. физичка неспретност узрокована дугачким и неспретним удовима, која се рефлектује и на друштвену. Кищощ такође не преноси у потпуности поруку лексеме $\operatorname{coxcomb}$, јер се ограничава на спољашњи изглед не говорећи ништа о другом начину на који се карактер испољава. Стога ауторка предлаже лексему надувенко, јер она преноси поруку и о карактеру и о његовим манифестацијама (надувенко $=$ онај који је надмен, иин себе, уображен, надувен, иррема: надувено = с висине, охоло, са жељом за самоистиицање, надмено, уображено, ирретенииозно).

Именица sweetmeats представља слатке колаче, пецива, кондиторске производе, кандирано воће, компот, зашећерено орашасто воће, бомбоне, слатке штапиће итд. У оба превода преводиоци су се одлучили за слайкище, што у потпуности покрива све наведене врсте, па и више. Ауторка предлаже још и йосласииие или слайкарије као могуће преводе. 
У наредном примеру поново имамо сведочанство о карактеру Џона Дешвуда, полубрата госпођица Дешвуд. Наиме, он је изузетно богат и обогатио се додатно наследивши имање „Норланд“ од оца, приморавши на тај начин своје полусестре да се иселе. Пошто је њихов заједнички отац сву ситнију имовину унутар куће завештао сестрама Дешвуд и њиховој мајци, према речима Џона Дешвуда, они су имали огромне трошкове да би набавили све што је потребно: постељину, порцелан, комплете за обедовање итд. Но, он не намерава да ройће, односно г̄унђа, како то преводе Милица Симеоновић и Бранислава Маодуш. Изворна лексема је to repine и подразумева управо изражавање незадовољства, негодовања, гунђање и жаљење на нешто. Прихватљива су оба превода, јер и према Речнику срӣског̄а језика ове лексеме подразумевају полугласно негодовање, изражавање протеста, срџбе, гнева, гунђање. Можда је за нијансу боље решење роййайи, јер је ређе у употреби, па тиме и ближе извору.

О карактеру госпође Ферарс, мајке Едварда и Роберта Ферарса, која се у роману лично појављује врло кратко и говори веома мало, сазнајемо пуно из судбина и карактера њених синова, ћерке и њених снаја, којима она управља. Због тога, када Луси Стил каже да је она affable, ми смо сигурни да то уопште није тако, али лексему морамо превести. Постојећи преводи су мила и срдачна. Ако знамо да је affable неко ко разговара и опходи се на лак, пристојан и углађен начин, онда видимо да ни један ни други превод не задовољава ову дефиницију у потпуности. О срдачном је већ било речи, а мила је она која изазива нежност, радост, угодност и друга пријатна осећања; љупка, дражесна. Ауторка предлаже придев ирријазна (услужна, љубазна, срдачна, пријатна, учтива), који такође није најбоље могуће решење, али делом дефиниције (учӣива) упућује на опхођење, што је кључни део дефиниције извора.

Како се роман ближи крају, и језик постаје мирнији и описи мање драматични. После емотивних бура, љубавних неспоразума и болести, на ред су дошли измирење, опоравак и лагано путовање кући. На почетку тог путовања пуковник Брендон помаже Меријен Дешвуд да уђе у кочију. Ту нам се појављује лексема engross (,... and bidding Colonel Brandon farewell with a cordiality of a friend, was carefully assisted by him into the carriage, of which he seemed anxious that she should engross at least half."), за коју је Милица Симеоновић понудила превод $\partial а$ юој остиане (,... и пошто се и с пуковником Бранденом поздравила срдачно и пријатељски, овај јој је помогао да се смести у кола, настојећи при том да юој остиане бар половина простора.”), а Бранислава Маодуш на расииолагағьу буде („Он јој је веома услужно помогао да се смести у кочију и добро је пазио да јој на расйолаг̄ању буде бар пола простора."). Oxford English Dictionary каже да је дефиниција лексеме engross „стећи или задржати искључиво власништво над нечим“", тако да је утисак да ни један ни други понуђени превод не одговара у потпуности. Наиме, прво решење подразумева да је Меријен ушла последња у кочију и да је пре њеног уласка пуковник Брендон сместио друге две путнице старајући се о томе да за Меријен остане више простора. То сматрамо немогућим, јер у 
наредној реченици списатељица каже да су се после ње у кочију попеле њена сестра и њихова мајка. Госпођа Џенингс је отишла чезама са служавком, а пуковник нешто касније, сам. Превод на расӣолаг̄ању буде је бољи, јер је неутралан у односу на редослед дешавања, али подразумева и конотацију коришћења по својој вољи, што аутоматски значи и да тог коришћења не мора да буде. Да је речено да расйолаже, било би приближније, јер према Речнику срйског̄ језика овај несвршени облик говори о поседовању, контролисању. Ауторка, ипак, предлаже другачије решење: да заузме, јер приближније дочарава „стицање и задржавање“ дефиницијом: „освојити, запосести, запремити неки простор“.

Следи пример за који у једном од превода нема решења. У питању је израз had been wont to believe. Овај израз се употребљавао уз инфинитив, у значењу used to. У тексту романа стоји да је госпођа Дешвуд била у заблуди у вези са Елинориним осећањима, те да се испоставило да су снажнија него што је она веровала да јесу. Милица Симеоновић је тако и превела - „него што је раније веровала да јесте...“, говорећи о њеној наклоности ка Едварду Ферарсу, док Бранислава Маодуш не преводи овај израз. Сматрамо да је понуђени превод релативно добар иако нису употребљене најприближније лексеме за used to (уобичајити, имати навику, навићи се, примити, прихватити), јер на српском језику нешто што се уобичајило или на шта се навикло имплицира дужи период, а радња у роману нам то не обезбеђује. Евентуално би се могло превести као „него што је у йочейку веровала да јесте...“, јер се мисли на прве дане познанства Едварда и Елинор, када су сви мислили да постоји снажна међусобна наклоност. Контекст откровења до којег је дошла госпођа Дешвуд је заправо тај да у драматичним догађајима око Меријен нико није обратио пажњу на Елинорина осећања, што списатељица констатацијом да је госпођа Дешвуд заведена у својим веровањима помало иронично наглашава.

На крају романа дешава се преокрет и списатељица каже: „The change which a few hours had wrought in the minds and the happiness of the Dashwoods, was such - so great - as promised them all, the satisfaction of a sleepless night." Превод из 1976. за означену лексему каже: врщиио свој уйлив („,Тај преокрет, који је већ неколико часова врщиио свој уйлив на душе и срећу Дешвудових, био је тако велики да им је свима осигурао бесану ноћ.”), док у преводу из 2012. стоји: врщии свој уйицај („Овај преокрет, који је неколико сати врщиио yйuцај на ум и срећу Дашвудових, био је толико неочекиван...и толико значајан да им је свима обећавао бесану ноћ.”). Оба превода сугеришу да је

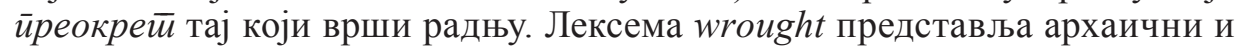
технички облик лексеме work. С обзиром на то да је овде употребљена фигуративно, пошто се неколико пресудних догађаја одиграло у веома кратком року, нарочито за ондашње појмове о времену, закључујемо да није преокрет вршио утицај или уплив на мисли Дешвудових неколико сати, него је само неколико сати обликовало, сииворило, ирроизвело, уобличило такву промену у мислима и срећи Дешвудових, такав преокрет да им је то гарантовало 
бесану ноћ. Дакле, акценат је на томе да се нешто важно преобликовало за врло кратко време, што и јесте случај, а то нас доводи до закључка да постојећи преводи не могу бити прихваћени као тачни.

„I was simple enough to think, that because my faith was plighted to another, there could be no danger in my being with уоu....". Едвард Ферарс наивно мисли да може слободно да се виђа са Елинор пошто је ионако већ дао некоме реч, односно, чащћу се обавезао друг̄oj. С обзиром на то да је овај израз у језику извору данас углавном песнички, реторички, ауторка сматра да би управо због тога примереније било употребити изразе попут: обећао се друг̄oj, заручио се са друг̃ом, дао веру друг̄ој, заветиовао се друг̄ој. Израз дайи реч, према субјективном осећају, има свечани тон, али му недостаје романтике, нарочито ако размишљамо на начин на који су размишљале хероине Џејн Остин. Иако је тај завет интиман и тајне природе, он у џентлменском свету XVIII века и те како има вредност писаног и потписаног документа. Милица Симеоновић чак преводи да је Едвард дао реч некоме, што додатно разводњава смисао. Чащћу се обавезайи, с друге стране, има романтични призвук и Бранислава Маодуш каже да се Едвард обавезао друг̄oj, што је у складу са разговором и међусобним објашњавањем између њега и Елинор. Међутим, будући да постоје бољи изрази (поменути горе), ауторка је мишљења да их је требало употребити.

3. ЗАКључАк. На крају можемо да изведемо закључке на два нивоа: на нивоу језика Џејн Остин и на нивоу постојећих превода романа Разум $и$ осећајности.

Што се језика Џејн Остин тиче, можемо да закључимо да, у односу на савремени енглески језик, на лексичком нивоу није архаичан у толикој мери да је неразумљив или теже разумљив данашњим читаоцима. На синтактичком нивоу такође није неразумљив данашњим читаоцима, али због редоследа речи у неким реченицама (нпр. Most unwilling was she to awaken from such a dream of felicity. (Austen 2000: 38)) језик романа делује песнички и застарело са данашњег становишта.

Као што смо раније напоменули, језик одсликава дух епохе, а жанр комедије нарави или друштвене комедије, можда то успева и у већој мери него неки други књижевни жанр. Стога је можда и најтежи преводилачки задатак при превођењу овог романа био очување тих финих језичких нијанси које упућују на време, место и друштво у којима се радња романа одвија. С обзиром на то да смо утврдили да језик Остинове није архаичан толико да је неразумљив говорнику савременог енглеског језика, задатак који подразумева разумљивост поруке на српском језику није био тежак.

Уопштено говорећи, можемо закључити да су, у смислу превода архаизама и историцизама, преводитељке Милица Симеоновић и Бранислава Маодуш у великој мери испуниле преводилачки задатак. У већини случајева преводна решења успешно преносе и појединачне комуникацијске поруке и тон романа, тако да је испуњен преводилачки задатак преношења поруке 
из језика извора у језик превода, при чему је сачуван и уметнички ниво преводилачког посла. Међутим, у неким од случајева, који су предмет анализе у овом раду, преводна решења су таква да не представљају ни формалне кореспонденте ни преводне еквиваленте, јер мењају смисао реченице, те недовољно прецизно или потпуно неуспешно преносе поруку из језика извора. Искључиво технички гледано, тиме се нарушава ток основног комуникацијског процеса о којем говори Ивир (1985). У светлу tertium comparationisa, тј. заједничког својства лексема које су контрастиране, значења лексема се, у случајевима у којима су преводи окарактерисани као неприхватљиви, не поклапају. У том смислу, чини се да основа за исправан превод појединих архаизама и историцизама није постављена, те на ширем плану задатак језичке операције декодирања поруке, као дела лингвистике, остаје у датим случајевима неиспуњен. Ипак, успешност целокупног превода не може се оцењивати на основу уског спектра лексема као што су то архаизми и историцизми, нити неколико неуспешних преводних решења могу нарушити општи утисак о преводу.

\section{ИЗВОРИ}

Остин, Џејн. Разум и осећајности. Београд: Народна књига, 1976.

Austen, Jane. Sense and Sensibility. Ware: Wordsworth Editions Limited, 2000.

Ostin, Džejn. Razum i osećajnost. Beograd: Alnari, 2012.

\section{ЦИТИРАНА ЛИТЕРАТУРА}

BUGARSKI, Ranko. Lingvistika i jezička kultura. Jezik u kontekstu. Beograd: Čigoja štampa, 1997: 250-256.

ERICKsON, Carolly. Our Tempestuous Day: A History of Regency England. New York: Harper Collins, 1986.

ĐorĐEvıć, Radmila. Uvod u kontrastiranje jezika. 4. izdanje. Beograd: Filološki fakultet, 2000.

IvIR, Vladimir. Teorija i tehnika prevođenja. 2. izdanje. Sremski Karlovci - Novi Sad: Centar „Karlovačka gimnazija” - Zavod za izdavanje udžbenika, 1985.

Krapp, George Philip. Is American English Archaic? Southwest Review 12/4 (1927): 292-303.

Melvinger, Jasna. Leksikologija. Osijek: Pedagoški fakultet, 1984.

NIDA, Eugene, Charles TABER. The Theory and Practice of Translation. Leiden: E. J. Brill, 1969.

Prćić, Tvrtko. Semantika i pragmatika reči. 2. dopunjeno izdanje. Novi Sad: Zmaj, 2008. 
Radovanović, Milorad. Sociolingvistika. 2. izdanje; Novi Sad: Književna zajednica Novog Sada - Dnevnik, 1986.

Radovanović, Milorad (ur.). Srpski jezik na kraju veka. Beograd: Institut za srpski jezik SANU - Službeni glasnik, 1996.

The British Monarchy (Official Site).

<http://www.royal.gov.uk/HistoryoftheMonarchy/KingsandQueensoftheUnitedKingdom/ TheHanoverians/GeorgeIII.aspx > 26. 2. 2013.

The British Monarchy (Official Site).

$<$ http://www.royal.gov.uk/HistoryoftheMonarchy/KingsandQueensoftheUnitedKingdom/ TheHanoverians/GeorgeIV.aspx > 26. 2. 2013.

DeForest Margolies, M., E. Johnson. Computing Latinate Word Usage in Jane Austen's Novels. $<$ http://users.ox.ac.uk/ ctitext2/publish/comtxt/ct18-19/24deforest-johnson. pdf $>$ 27. 2. 2013.

\section{РЕЧНИЦИ}

PMC: Речник срӣског̄а језика. Нови Сад: Матица српска, 2007.

The American Heritage Dictionary of the English Language. 5th edition. Houghton Mifflin, Boston, 2011. <http://www.ahdictionary.com>

Cambridge Advanced Learner's Dictionary. 2nd edition. Cambridge University Press, Cambridge. (i na CD-ROMu), 2005.

The Chambers Dictionary. 12th edition. Chambers Harrap Publishers Ltd., London, 2011. $<$ http://www.chambers.co.uk/search.php?query $=\&$ title $=21$ st $>$

Collins English Dictionary. 11th edition. Collins, London, 2011.

$<$ http://www.collinsdictionary.com/dictionary/english>

Collins COBUILD English Language Dictionary. London: Harper Collins Publishers, 1993.

LaLEvić, M. Sinonimi i srodne reči srpsko-hrvatskog jezika. Beograd: Leksikografski zavod - Sveznanje, 1974.

Merriam-Webster's Collegiate Dictionary. 11th edition. Merriam-Webster, Springfield, 2003. <http://www.merriam-webster.com >

Oxford Dictionaries On-line: British and World English. <http://www.oxforddictionaries.com> Oxford English Dictionary. 2nd edition. (on CD-ROM). Oxford: Oxford University Press, 2009. 
Nataša V. Gojković

TRANSLATION OF ARCHAISMS AND HISTORICISMS FROM ENGLISH INTO

SERBIAN LANGUAGE IN JANE AUSTEN'S NOVEL SENSE AND SENSIBILITY:

A CRITICAL ANALYSIS

\section{Summarry}

This paper deals with translation of archaisms and historicisms from English into Serbian language in Jane Austen's novel Sense and Sensibility. The novel was translated into Serbian language twice: in 1976 by Milica Simeonović and in 2012 by Branislava Maoduš. In this paper, the basis for the analysis of different translation solutions is a universal language characteristic or tertium comparationis - the third element according to which the comparison is made. All historicisms found in the novel were analyzed, while archaisms were chosen according to the following criteria: 1) their translations differ in the two existing translations of the novel and 2) the author of the paper offers a better solution for their translation. In the Introduction, the concepts of archaisms and historicisms are briefly explained, the dictionaries that were used in the analysis are listed, the theoretical ground is set and the translator's task in Sense and Sensibility is introduced. The next part of the paper is dedicated to a detailed analysis of the translation of archaisms and historicisms i.e. comparison of the definitions of the meanings of the lexemes singled out to the definitions of the meanings of their translations. In some cases, a better translation is offered. The meanings of the lexemes in English were taken exclusively from the Oxford English Dictionary (electronic edition), while the meanings of the lexemes in Serbian were taken from Rečnik srpskoga jezika and the lexicon Sinonimi i srodne reči srpskohrvatskog jezika. The third part of the paper lists several basic conclusions of the analysis on the level of the language of Jane Austen and on the level of the existing translations of archaisms and historicisms in the novel. The general conclusions in that sense are as follows: a) the language of Jane Austen is not archaic to the point of being unintelligible to the modern reader and $b$ ) the translation by Milica Simeonović can be considered better than the one by Branislava Maoduš, which can be concluded on the basis of the translation solutions offered for archaic and historical lexemes.

Key words: archaisms, historicisms, tertium comparationis, Sense and Sensibility, translation

Univerzitet u Novom Sadu

Pedagoški fakultet u Somboru

Podgorička 4, 25000 Sombor

natasa.gojkovic@pef.uns.ac.rs 